\title{
Питання психології
}

УДК: 159.9

DOI: $10.33099 / 2617-6858-21-62-4-41-47$

Гульбс О. А. доктор психологічних наук, професор кафедри психології Уманського державного педагогічного університету імені Павла Тичини, https://orcid.org/0000-0002-5300-8570

Кобец О. В. доктор психологічних наук, професор кафедри психології Уманського державного педагогічного університету імені Павла Тичини https://orcid.org/0000-0002-9096-6313

\section{РОЗВИТОК ЕМОЦЙНОЇ КОМПЕТЕНТНОСТІ СТУДЕНТІВ-ПСИХОЛОГІВ У ГРУПАХ АКТИВНОГО СОЩАЛЬНО-ПСИХОЛОГІЧНОГО НАВЧАННЯ}

У статті розкривається значущість у структурі особистості студентів-психологів емоиійних здібностей (емпатії, рефлексії, саморегуляиії та управління почуттями та емоиіями інших людей). Специфіка праиі психолога полягає в тому, щу фахівиеві необхідно протистояти професійним труднощам, управляти своӥм емочійним станом.

Ключові слова: студенти-психологи; професійна компетентність; емоційна компетентність; емоційні здібності; професійні труднощі; емоиійний стан.

Вступ. У сучасних умовах в системі освіти відбуваються глобальні зміни в інформаційній, комунікаційній, професійній та інших сферах. Змінюються ціннісні орієнтації, цільові установки, педагогічні засоби, відбувається коригування змістовних, методичних, технологічних аспектів освіти. Крім того змінюються вимоги до фахівців психологічних спеціальностей. Сучасний психолог повинен бути готовий теоретично i практично вирішувати професійні завдання, вміти створювати, застосовувати і коригувати систему професійної діяльності.

Мета дослідження - обгрунтувати засоби діагностичної та корекційної роботи, що сприяють розвитку емоційної компетентності; розробити та обгрунтувати програму розвитку емоційної компетентності у студентів-психологів.

\section{Теоретичне підгрунтя (огляд} літератури і попередніх досліджень 3 цісї чи суміжної проблематики). Т.В. Заморська визначає професійну компетентність психолога як складну психологічну освіту, яка виступає основою успішної професійної діяльності, включає в себе систему діяльнісно-рольових (знання, вміння i навички) і особистісних (професійно важливі якості) характеристик [2].
B.I. Стенькова, розглядаючи професійну компетентність психолога, виділяє спеціальну (володіння методиками i техніками), персональну (здатність до самореалізації, постійного професійного зростання), комунікативну (вміння встановлювати взаємини з суб'єктом освітнього процесу) i рефлексивну (вміння регулювати свою професійну діяльність, адекватне уявлення про свої професійні характеристики) компетенції [6].

Специфіка праці психолога полягає в тому, що фахівцеві необхідно протистояти професійним труднощам, управляти своїм емоційним станом, визначати особливості свого впливу, проявляти перцептивні здібності, вміти розуміти позицію інших, розуміти індивідуальність і неповторність іншої людини, емпатувати йому, рефлексувати. Крім того професія психолога супроводжується постійними психоемоційними перевантаженнями, емоційною напруженістю, емоційним вигоранням і т. д. Отже, найбільшу значимість в структурі особистості психолога мають емоційні здібності (емпатія, рефлексія, саморегуляція i управління почуттями та емоціями інших людей).

Е. В. Лібіна, вивчаючи індивідуальні відмінності в реагуванні на стрес, вводить 


\section{Питання психології}

поняття емоційної компетентності, яку визначає як здатність особистості здійснювати оптимальну координацію між емоціями i цілеспрямованою поведінкою. Надалі автор розглядає поняття емоційної компетентності з точки зору психотерапевта, протиставляючи його захисній поведінці і при цьому залишаючи в тіні склад, структуру і властивості цього інтегрального освіти [3].

На думку Г.В. Юсупової, розумові здібності і компетентність розглядаються як пов'язані з одними і тими ж психологічними механізмами Г.В. Юсупова розглядає емоційну компетентність як групу здібностей до саморегуляції i регуляції інтерперсональних відносин шляхом розуміння власних емоцій і емоцій оточуючих [8].

Узагальнюючи вищесказане, можна відзначити, що індивіди 3 високим рівнем розвитку емоційної компетентності мають виражені здібності до розуміння власних емоцій і емоцій інших людей, до управління емоційною сферою, що обумовлює більш високу адаптивність і ефективність в спілкуванні.

Емоційна компетентність, як складова професійної компетентності, являє собою сукупність емоційних і соціальних здібностей, таких як здатності до розуміння власних емоцій і емоцій інших людей, до управління емоційною сферою. Всі структурні компоненти емоційної компетентності взаємопов'язані, і їх тісна взаємозалежність сприяє ефективному міжособистісному взаємодії.

Методи дослідження. В нашому дослідженні ми навчали студентів, професійно вірно та ситуативно обумовлено вступати в спілкування, прогнозувати емоційні реакції партнерів зі спілкування на власні дії, психологічно настроюватися на емоційний тон співрозмовників, емоційне настроюватися на ситуацію спілкування, психологічно «пристроюватись» до співрозмовника, адекватно ситуації вибирати жести, пози, ритм своєї поведінки - це лише деякі аспекти, рішення яких дозволить студентам ефективно навчатися і працювати використовуючи навички емоційного інтелекту. Розробляючи проблему розвитку емоційної компетентності студентів ми вважаємо що ii можна вирішити не тільки просвітою та підвищенням загальної культури, але й спеціальними заняттями розвитку емоційної компетентності і в першу чергу, професійно спрямованими. Нами застосовано комплекс теоретичних методів i прийомів: теоретико-методологічний аналіз, осмислення, порівняння й узагальнення основних положень наукових джерел, що відповідають темі та меті дослідження. При реалізації програми використовувались наступні методи: дискусія, інтерв'ювання, міні-лекції, круглі столи, тематичні дискусії, творча діяльність (проект), ділові ігри, рольові та імітаційні ігри, відеоконференції.

На заняттях ми наділяли увагу важливим елементам навчання навичкам емоційної компетентності студентів, професійним прийомам взаємодії, та труднощам, які зустрічаються в процесі міжособистісних контактів.

Застосування методів активного соціально-психологічного навчання (АСПН) у ВШ дозволяє учасникам розвинути навички спілкування і взаємодії в малій групі, сформувати ціннісно-орієнтаційну єдність групи; навчити гнучкій зміні соціальних ролей залежно від ситуації, прийняттю моральних норм і правил спільної діяльності, розвинути навички аналізу і самоаналізу в процесі групової рефлексії. Активне соціально-психологічне навчання в системі "Викладач - група" сприяє нестандартним стосункам в організації освітнього процесу, формуванню мотиваційної готовності до міжособистісної взаємодії в учбових i професійних ситуаціях (Вачков I.В., 2011).

В дослідженні нами розроблена корекційно-розвиваюча програма "Розвиток емоційної компетентності студентів майбутніх фахівців" у групах активного соціально-психологічного навчання, яка мала наступні завдання:

1. Виявлення рівня емоційного інтелекту членів групи;

2. Збагачення учасників групи знаннями про сутність емоційної компетентності, iii характеристики та ефективність міжособистісної взаємодії; 


\section{Питання психології}

3. Навчання елементам емоційного інтелекту, та розвиток навичок самоконтролю і емпатійних відносин у взаємодій з іншими;

4. Допомога в адекватному самооцінюванні, самоаналізу і саморефлексії;

5. Розвиток емоційної зрілості та чуттєвого сприйняття іншого;

6. Зняття негативних установок до інших;

7. Розвиток емоційної компетентності, загальної комунікативної толерантності, спостережливості та здібностей до емоційного інтелекту.

Згідно 3 завданням роздробленої нами програми, ми досягали мети перспективними і діяльнісними засобами впливу на студентів майбутніх фахівців, ї емоційні, комунікативні здібності та комунікативну компетентність. В дослідженні ми прагнули до розвитку у студентів навичок самопізнання, самоаналізу, самореалізації, підвищення моральних принципів взаємодії та позитивного ставлення до інших, що дозволило більш ефективно розвивати емоційній інтелект членів групи. Важливу роль в розвитку емоційної компетентності має участь студентів у тренінгових заняттях, виконанні спеціальних вправ та психологічних ігор. Найбільший інтерес студенти проявили при виконанні таких вправ: «Емоційне слухання», «Усмішка», «Асоціації», «Свій стиль», «Відвертість», «Стійкість», «Емоції і злість», «Приємні спогади», «Скульптура», «Очі. Погляд», «Жести. Поза», «Настрій», «Візуалізація», «Подарунки», «Сімейний альбом». Згідно 3 програмою розвитку емоційного інтелекту студентів для них приводились такі тренінгові заняття: «Розвиток емоційного інтелекту», «Особистісне зростання», «Емоційна стійкість», «Позитивне самовиховання та впевнена поведінка». На тренінгових заняттях використовувались такі психологічні ігри: «Корабельна аварія», «Твоє обличчя», «Пошук скарбів», «Хто я?», «Два королівства», «Перестановка ролей».

Відповідно до корекційно-розвиваючої програми "Розвиток емоційної компетентності студентів - майбутніх фахівців" в групах активного соціальнопсихологічного навчання (АСПН), підібрано комплекс методів для проведення занять, які відповідають поставленій перед нами меті. Згідно 3 програмою проводилась групова практична робота. Специфіка даної програми в тому, що вона має спрямованість на зміну поведінки, на розвиток емоційної компетентності, емоційного інтелекту, емоційно-вольових, когнітивних якостей особистості. В основі продуктивного, якісного проходження програми лежить співпраця, цілеспрямованість діяльності i щирість у вираженні своїх думок, а також, активність студента i його творче, дослідницьке ставлення до занять. Застосовуваний комплекс методів формувався за зростанням рівня складності завдань. Ефективність застосованої програми проявлялась у підвищенні рівня емоційної компетентності майбутніх фахівців, що фіксується за допомогою застосування психодіагностичних методик, і об'єктивної реєстрації змін їх особистості. За масштабу розв'язаних завдань оптимізації розвитку емоційної компетентності майбутнього фахівця, надання емоційної підтримки та інформації про позитивні аспекти проходження програми підводило студентів до розуміння його бажання участі в проекті, та обговорювались їх очікування від програми та організації занять. Підібрані нами методики орієнтовані на відпрацювання вербального i невербального спілкування, перцептивних навичок, сприйняття і уявлення, встановлення взаєморозуміння, розуміння себе, вивчення основ психофізіогноміки, відпрацювання комунікативних навичок та навичок емоційного інтелекту.

Дослідження розвитку емоційної компетентності у студентів проводилося нами на базі «Уманського державного педагогічного університету імені Павла Тичини». У дослідженні взяли участь 56 студентів.

Дослідження проходило протягом ряду етапів:

- психодіагностика рівня емоційної компетентності у студентів 3 використанням наступних методик: "Методика дослідження соціального інтелекту" Дж. Гілфорда і М. Саллівена, опитувальник «Емоційний 


\section{Питання психології}

інтелект» Д. В. Люсіна (Михайлова Е.С., 2006; Люсин Д.В., 2009; Вачков І.В., 2007);

- впровадження корекційно-розвиваючої

програми "Розвиток емоційної компетентності студентів - майбутніх фахівців" в групах активного соціальнопсихологічного навчання (АСПН);

- виявлення рівня розвитку емоційної компетентності у студентів та ефективності розробленої програми активного соціальнопсихологічного навчання "Розвиток емоційної компетентності студентів - майбутніх фахівців" в групах (АСПН).

На першому етапі дослідження використовувалась методика Дж. Гілфорда i M. Саллівена дослідження соціального інтелекту. Основне призначення даної методики - діагностування когнітивної складової комунікативної компетентності людини. Обрана методика визначає рівень "соціального інтелекту". Соціальний інтелект - це інтегральна інтелектуальна здатність, що визначає успішність спілкування і соціальної адаптації, яка об'єднує і регулює пізнавальні процеси, пов'язані 3 відображенням соціальних об'єктів (людини як партнера по спілкуванню або групи людей). До процесів, що його утворюють, відносяться соціальна чутливість, соціальна перцепція, соціальна пам'ять і соціальне мислення.

В дослідженні використовувався опитувальник «Емоційний інтелект» (Емін) розроблений Люсіним Д. В., в якому виділяється 4 шкали: міжособистісний інтелект (MEI), внутрішньоособистісний інтелект (BEI), розуміння емоцій (PE), управління емоціями (УЕ).

На першому етапі дослідження, були отримані наступні результати: у $37,5 \%$ студентів було діагностовано середній рівень розвитку емоційної компетентності, у 13,75\% - високий і у 48,75 - низький.

\section{Результати і обговорення.}

Аналізуючи підходи до підготовки студентів вищої школи, майбутніх фахівців слід відмітити:

- недостатню розробленість науковопедагогічних основ формування емоційної компетентності і необхідність іï формування у студентів в процесі професійної підготовки;
- необхідність розвитку емоційної компетентності у студентів як особовопрофесійної якості;

потрібність суспільства в кваліфікованих фахівцях здатних розвивати у студентів емоційну компетентность у навчальному процесі.

Розвиток емоційної компетентності у студентів вищої школи найуспішніше можна здійснювати в тренінгових групах. Якщо IQ мало міняється в зрілому віці, то EQ, в основі якого лежить досвід управління собою $\mathrm{i}$ оточенням, може і повинен зростати. На думку авторів (Бар-Он Р., Гоулман Д., Майєр Д.), найбільш оптимальним засобом розвитку емоційної компетентності є участь студентів в тренінгових заняттях. Бар-Он пропонуе проводити тренінгові зайняття на протязі тривалого часу. Він вважає, що це дасть можливість не просто розвинути необхідні компоненти емоційного інтелекту, але i закріпити отримані зміни в поведінці людини (Bar-On R., 2000). Гарднер Г., стверджує, що будь-яка людина здатна вчитися i розвивати рівень емоційної компетентності за допомогою постійної практики (Гарднер Г., 2007). У зв'язку з цими дослідженнями Вачков I.B., виділив наступні переваги психокорекційної роботи в групах:

- груповий досвід протидіє відчуженню, допомагає рішенню міжособистісних проблем;

- група відбиває суспільство в мініатюрі, робить очевидними такі приховані чинники, як тиск партнерів, соціальний вплив i конформізм;

- можливість отримання зворотного зв'язку і підтримки від людей 3 схожими проблемами;

- в групі людина може навчатися новим умінням, експериментувати 3 різними стилями стосунків серед рівних партнерів;

- i усе це в атмосфері доброзичливості, прийняття і підтримки;

- в групі учасники можуть ідентифікувати себе з іншими, "зіграти" роль іншої людини для кращого розуміння його i себе і для знайомства 3 новими ефективними способами поведінки; 


\section{Питання психології}

- взаємодія в групі створює напругу, яка допомагає прояснити психологічні проблеми кожного;

- група полегшує процеси саморозкриття, самодослідження і самопізнання (Вачков I.B., 2001).

Розвиток емоційної компетентності, як складної інтеграційної освіти, що забезпечує усвідомлення, розуміння і регуляцію власних емоцій і емоцій оточення, буде ефективним при реалізації моделі розвитку емоційного інтелекту, що враховує структуру емоційного інтелекту і включає: цільовий блок; форми організації учбового процесу; методи розвитку емоційного інтелекту; етапи розвитку емоційного інтелекту; прогнозований результат і програму розвитку емоційного інтелекту, важливою частиною якої $\epsilon$ групове зайняття 3 використанням активних методів соціально-психологічного навчання (АСПН) (Слепкова В.І., 1997).

Активне соціально-психологічне навчання (АСПН) студентів $\epsilon$ психологопедагогічною формою розвитку емоційної компетентності i вдосконалення умінь i навичок взаємодії в суспільстві, здійснюваної в умовах групової навчально-тренувальної діяльності. На взаємодію студентів в навчальній групі впливає модель їх відносин в соціумі. АСПН нами застосовувалось для формування у студентів специфічних емоційних, комунікативних, когнітивних та поведінкових умінь, 3 метою підвищення емоційної компетентності, комунікативної та психологічної компетентності, емоційного інтелекту. Активне навчання спрямоване на самостійне оволодіння студентом знаннями та вміннями використовувати досвід розвитку емоційної компетентності.

Аналіз навчальної діяльності студентів показав, що для того, щоб успішно виконувати свою роботу, майбутній фахівець повинен мати добрі спеціальні професійні здібності, до яких відносяться ті здібності, що впливають на його успішну професійну діяльність. Емоційна компетентність $\epsilon$ важливим елементом цілісної системи успішної професійної діяльності майбутніх фахівців.

Після проведення корекційнорозвиваючої програми були отримані наступні результати: низький рівень показали - $17.5 \%$ студентів; середній рівень - 58.3\%; високий $-24.2 \%$.

Відбулося значне підвищення середніх i низьких показників розвитку емоційної компетентності студентів. Активне соціально психологічне навчання студентів в групах $(\mathrm{ACПН),} 3$ використанням корекційнорозвиваючої програми "Розвиток емоційної компетентності студентів - майбутніх фахівців" показало свою ефективність, але потребує iі удосконалення, для використання на другій ступені розвитку емоційного інтелекту у студентів, що надає змогу студентам 3 низьким та середнім рівнями розвитку емоційного інтелекту покращити свої результати.

Таким чином, впливаючи методами соціально-психологічного навчання (АСПН), стимулюючи розвиток емоційної компетентності за допомогою програми "Розвиток емоційної компетентності студентів - майбутніх фахівців", організовуючи роботу в групах, можна сформувати установки на управління емоціями.

\section{Висновки.}

Емоційна компетентність розуміється як здатність усвідомлювати емоції, досягати і генерувати їх так, щоб сприяти розумінню емоцій і управляти ними, сприяючи своєму емоційному і інтелектуальному зростанню. Емоційна компетентність пов'язана із здібностями, які означають: точність оцінки і вираження емоцій, як самого індивіда, так і людей, що оточують його; когнітивну асиміляцію емоційного досвіду; розпізнавання, розуміння i осмислення емоцій. Ефективність роботи в групах активного соціально-психологічного навчання (АСПН) із студентами висока, оскільки сам по собі юнацький вік припускає рухливість, пластичність i сенсітівность емоційної i інтелектуальної сфер особистості. Робота в групах АСПН спрямована на позитивні зміни в розвитку емоційної компетентності у студентів. Розвинена емоційна компетентність майбутніх фахівців $\epsilon$ важливою умовою життєвого успіху, задоволеності і упевненості в професійній діяльності. Існує потреба в подальшому 


\section{Питання психології}

дослідженні феномену емоційної усвідомлення емоційних станів, що компетентності, ऑiі структури, шляхів іiі виникають в професійній діяльності розвитку, що відкриє реальну можливість майбутніх фахівців. оптимізації взаємовідносин через глибше

\section{Список використаних джерел}

1. Гоулман Д., Бояцис Р., Макки Э. Эмоциональное лидерство: искусство управления людьми на основе эмоционального интеллекта. - М.: Альпина Бизнес Букс, 2005. - 350с.

2. Заморская Т.В. Психолого-педагогические особенности совершенствования профессиональной компетентности педагогов-психологов в условиях ИПК: Учеб.-метод. пособие. - Тамбов: ТОИПКРО, 2003. $-51 \mathrm{c}$.

3. Либина Е.В., Либин А.В. Стили реагирования на стресс // Стиль человека: психологический анализ.М.: Смысл, 1998.- 204 с.

4. Манойлова М.А. Акмеологическое развитие эмоционального интеллекта учителей и учащихся. Псков: ПГПИ, 2004. - 140 с.

5. Петровский А.В., Ярошевский М.Г. Психология. Словарь.- М, 1990.- 400 с.

6. Стенькова В.И. Педагогическая практика как фактор развития профессиональной компетентности будущих психологов, преподавателей психологии: автореф. дис. ... канд. пед. наук. - Улан-удэ, 2007. - 22 с.

7. Юсупов И.М. Психология взаимоотношений. - Казань, 1991. - 250 с.

8. Юсупова Г.В. Состав и измерение эмоциональной компетентности: дис. ... канд. психол. наук. Казань, 2006. -208 с.

9. Mayer J.D. Emotional intelligence information, 2005.

10. Salovey P., Mayer J.D. Some final thoughts about personality and intelligence // Stenberg J., Ruzlis P. (eds). Personality and intelligence. Cambridge: Cambr. Univ. Press, 1994.

\section{References}

1. Houlman D., Boiatsys R., Makky Э. (2005) Эmotsyonalnoe lyderstvo: yskusstvo upravlenyia liudmy na osnove эmotsyonalnoho yntellekta [Emotional Leadership: The Art of Managing People Based on Emotional Intelligence]. - M.: Alpyna Byznes Buks. - 350 s. (in Russian)

2. Zamorskaia T.V. (2003) Psykholoho-pedahohycheskye osobennosty sovershenstvovanyia professyonalnoi kompetentnosty pedahohov-psykholohov v uslovyiakh YPK [Psychological and pedagogical features of improving the professional competence of educational psychologists in the conditions of IPC]: Ucheb.-metod. posobye. Tambov: TOYPKRO. - 51 s. (in Russian)

3. Lybyna E.V., Lybyn A.V. (1998) Styly reahyrovanyia na stress [Stress Response Styles // Human Style] // Styl cheloveka: psykholohycheskyi analyz. - M.: Smbsl. - 204 s. (in Russian)

4. Manoilova M.A. (2004) Akmeolohycheskoe razvytye эmotsyonalnoho yntellekta uchytelei y uchashchykhsia [Acmeological development of emotional intelligence of teachers and students]. - Pskov: PHPY. - 140 s. (in Russian)

5. Petrovskyi A.V., Yaroshevskyi M.H. (1990) Psykholohyia. Slovar [Psychology. Dictionary]. - M. - 400 s. (in Russian)

6. Stenkova V.Y. (2007) Pedahohycheskaia praktyka kak faktor razvytyia professyonalnoi kompetentnosty budushchykh psykholohov, prepodavatelei psykholohy [Pedagogical practice as a factor in the development of professional competence of future psychologists, teachers of psychology]: avtoref. dys. ... kand. ped. nauk. - Ulanudэ. -22 s. (in Russian) Russian)

7. Yusupov Y.M. (1991) Psykholohyia vzaymootnoshenyi [Relationship psychology]. - Kazan. - 250 s. [(in

8. Iusupova H.V. (2006) Sostav y yzmerenye эmotsyonalnoi kompetentnosty [Composition and measurement of emotional competence]: dys. ... kand. psykhol. nauk. - Kazan. - 208 s. (in Russian)

9. Mayer J.D. (2005) Emotional intelligence information.

10. Salovey P., Mayer J.D. (1994) Some final thoughts about personality and intelligence // Stenberg J., Ruzlis P. (eds). Personality and intelligence. Cambridge: Cambr. Univ. Press. 


\section{Питання психології}

\section{Резюме}

Гульбс О. А. доктор психологических наук, профессор, профессор кафедры психологи Уманского государственного педагогического университета имени Павла Тичины

Кобец О. В. доктор психологических наук, профессор профессор кафедры психологи Уманского государственного педагогического университета имени Павла Тичинь

\section{РАЗВИТИЕ ЭМОЦИОНАЛЬНОЙ КОМПЕТЕНТНОСТИ СТУДЕНТОВ-ПСИХОЛОГОВ В ГРУППАХ АКТИВНОГО СОЦИАЛЬНО-ПСИХОЛОГИЧЕСКОГО ОБУЧЕНИЯ}

В статье раскрывается значимость в структуре личности студентов-психологов эмочиональныхх способностей (эмпатии, рефлексии, саморегуляции и управления чувствами и эмоциями других людей). Специфика труда психолога заключается в том, что специалисту необходимо противостоять профессиональным трудностям, управлять своим эмочиональным состоянием.

Ключевые слова: студенты-психологи; профессиональная компетентность; эмоциональная компетентность; эмоииональные способности; профессиональные трудности; эмоциональное состояние.

\section{Summary}

Gulbs $\boldsymbol{O}$. Uman state pedagogical university named after Pavlo Tychyna

Kobets $\boldsymbol{O}$. Uman state pedagogical university named after Pavlo Tychyna

DEVELOPMENT OF STUDENTS-PSYCHOLOGISTS' EMOTIONAL COMPETENCE IN ACTIVE SOCIAL-PSYCHOLOGICAL GROUPS

Introduction. The successful performance of professional functions by a psychologist directly depends on his ability to build constructive interpersonal relationships with others. It is important for him to form a willingness to understand different people, the ability to navigate in different models of their lives, the ability to interact with them, to see their uniqueness and uniqueness, to accept their advantages and disadvantages. Therefore, the effective work of a psychologist directly depends on his developed emotional competence.

Purpose. To substantiate the means of diagnostic and corrective work that promote the development of emotional competence; to develop and substantiate the program of development of emotional competence in students-psychologists.

Methods. Quantitative and qualitative methods have been used. Quantitative research methodology involved the use of numerical data to make descriptions, predict outcomes, and test potential relationships between variables.

Originality. The use of methods of active socio-psychological learning allows participants to develop communication and interaction skills in a small group, to form a value-oriented unity of the group; to teach flexible change of social roles depending on a situation, acceptance of moral norms and rules of joint activity, to develop skills of the analysis and self-analysis in the course of group reflection. Analysis of students' learning activities showed that in order to successfully perform their work, the future specialist must have good special professional abilities, which include those abilities that affect his successful professional activity. Emotional competence is an important element of a holistic system of successful professional activity of future professionals. After the correctional and developmental program there was a significant increase in medium and low rates of development of emotional competence of students. The following results were obtained: $17.5 \%$ of students showed a low level; the average level - 58.3\%; high - 24.2\%. Thus, the effectiveness of work in groups of active socio-psychological learning with students is high, because in itself adolescence implies mobility, plasticity and sensitivity of the emotional and intellectual spheres of personality.

Conclusion. Work in groups of active socio-psychological training is aimed at positive changes in the development of emotional competence in students. There is a need for further study of the phenomenon of emotional competence, its structure, ways of its development, which will open a real opportunity to optimize the relationship through a deeper understanding of emotional states that arise in the professional activities of future professionals.

Keywords: psychology students; professional competence; emotional competence; emotional abilities; professional difficulties; emotional condition.

Автори заявляють про відсугність конфлікту інтересів.

Recelved/Поступила: 27.08.21. 